\title{
The Community Trend in Training of Child Psychiatrists
}

HE story goes that once a young psychiatric patient saw a man out on the street and wondered how it was that this man could look so much like his therapis-never thinking that it might be the same person. Should the new trend in the training of child psychiatrists continue, perhaps one day a similar child roy not recognize his therapist if he meets him in a private office.

The core training program in child psychiatry in most centers fulfills the requirements set down by the American Board of Psychiatry and Neurology in 1959 - wo years in adult psychiatry, followed by two years in chid psychiatry. The basic training, being clinically oriented, is aimed at teaching skills in diagnosis and in dynamics, as well as in therapeutc technics. This is accomplished through individual supervision, with an admixture of didactic colurses, seminars, and informal conferences. Experience in research, administration and in teaching is also encouraged Nost of the training takes place in out-patient clinics, although some centers provide in patient and occastonally day care programs Some training programs emphasize experience directly in the community.

Child Psychiatry as a specialty focuses on the child and his environment. This includes emphasis on the members of the family and their mutual interactions. The child's environment includes his school, his neighborhood, and often some agencies or organizations. To bypass these means to ignore significant portions of the child's life. That is why most child psychiatry training programs tend to encourage school visits and conferences with juve. nile authorities whenever pertinent.

In many training centers, the child psychiatrist is moving from the offce tro the commonity. This trend has important advantages and disadvantages as $1 \mathrm{t}$ afects he training of the hid pydhiary resit dent, the specialty in general, and the community tas 2 whole

\section{Current Approach to Community Psychiatry}

The child poychiatrist way become lavolved in the communt either in individual treatment of Individual dillaren, or as a consultant, a teacher, or an advisor to community agencies.

When he is functioning in the community as a consulane he is not acting primarily as a therapist, intervening or gathering information about a particular child, but rather as a specialist advising some specific community group.

Realizing the value of such experiences, many training programs arrange for the resident to do some consulting work in his second year of training. He may be assigned to a child guidance clinic, a corrective insticution, a school system, or to a variety of different agencies.

When the psychatrist or the resident in training starts out in this endeavor, he is usually looked upon as a "problem solver" That is, he is frequently placed in the role of an evaluator and asked to advise on dispositions in individual cases. Fortunately, this role does not last very long. He soon tends to become a "teacher" to the personnel of the agency where he consults, He provides insights and understanding, along with translating his psychiatric terminology into meaningful language for the staf, so that they, in turn, can view the problems dynamically and thereby reach logical solutions. From such instruction the personnet can use their new knowledge to help solve other similar problems. For example, the child psychi atrist acting as a consultant may help a school handle a school phobic child or a truant child within the school setting. Thenceforth the school personnel may be able to handle other minor or transient problems themselves, seeking suggestions from the consultant only as needed.

Another example of how this approach can work is the provision of consultation to practicing pediatricians. These physicians are frequently confronted by overanxious mothers, psychophysiologic disturbances, etc. They usually prefer to handle the minos emocional problems by counseling or reassurance, and refer for more skilled assistance onty hose pathents in whom the emotional wiflcully is beyond heir capacity When a child psy

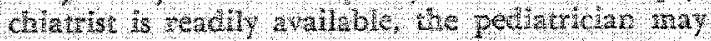
obtain a phone consultation from him or, if the difficlty in the case warrants it, he may ask for a psychiatric evaluation. After the evaluation, the pediatrician and psychiacist discuss the fintings together and agree on a suitable plan of action. The pediatrician may then continue to handle the case, sceking further psychatric advice only if needed. 


\section{Advantages and Problems}

As the child psychiatrist in training goes into the community to teach, some problems, as well as important advantages, may arise.

It is important that the search for basic dynamic understanding of children not be sacrificed to accommodate the consulting program. The program must be regarded as an addition lo, rather than as a substitute for, the usual learning experience. Otherwise, the consulting "teacher" will acquire no background of insights from which to teach. And it would be self-destructive if the trend resulted in the extreme that the therapist would be working in the community so much he would be too busy to do therapy.

Actually, one of the goals of consultation activity is to give the therapist more time for management of appropriate cases. The consultant is in the community not so much to teach other mental health professionals or laymen how to become junio: yrade psychiatrists, as to enhance their understanding of basic mental health concepts. Inevitably this should provide not only more expedient handling of behavior problems, but also more appropriate guidelines for referrals.

\section{Community Psychiatry in the Future}

To make the community activities in child psychiatry successful, many more child psychiatrists are needed. Having residents do the consulting does not provide enough manpower for an adequate job. Almost all the practicing child psychiatrists must join in carrying some of this load.

It is not true that child analysts as a group are reluctant to become thus involved. Many child analysts are leaders in this new approach. Any one who can get down on all fours to play soldiers with a young patient should have no difficulty in squeezing into a classroom chair to conduct a conference in a schoolroom-MARTA PALUszNY, M.D., Instructor in Psychatry at the Unizersity of Michlgan Medical School, Ann Arbor, Mich. 48104.

\section{Rock 'n Roll Music: Harmful?}

S y. Jackhammers in the streets. Deafening traffic noises. These capture the major attention of those officers whose job it is to cope with the ever-increasing din in our busy world. But is part of their attention misplaced? Are they overlooking a source of noise which is both more extended and potentially more damaging to the hearing of our young people?

This month we feature two fascinating articles which indicate that our teenagers listening tastes in music may lead to significant impairment of cheir hearing, Trs. Rupp and hoch describe the effects of prolonged exposure to overly loud rock $n$ roll wasic ypon the hearing acuity of five nombers of a rock masic combo. And Dr. 4 ipscomb reports

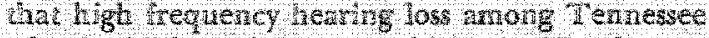
school children increases with age. He demon strates also, through a series of extraordinary pictures, the damage to vital cochlear tissues of a guinea pig exposed to rod a roll masic recorded at a discolfeque Trequency of $120 \mathrm{~dB}$.

In an earlier less complicated era, industry and the military were alone in their desire for hearing conservation programs. Now, saddenly, recrea- thonal music has become a matter of concern to audiologists who in turn are appealing to us the pediatricians, to help alert adolescents and their parents to this potential danger.

\section{See articles on pages 60 and 63}

Teenagers, aheady suspicious of our generation for condemning their speech, ridiculing their long hair and mocking their clothes, may well find a frontal attack on their music listening habits

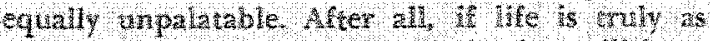
unreal to them as they tell us it is, they still have therr rasic-thelonder, the betwer.

Our obligation 18 dear the impled cause and

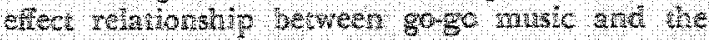
rising Incidence among our chidren of high trequency hearing impaiment must sput eforts to secure safeguards for our chlldren's hearing, If we fail in this dury, the potential cost in the form of personal tragefy is immeasurable. The teenagers? ability to "turn us off" by not listening, may change to a situation where they can no longer "turn us on" again $\rightarrow A L A N$ R. FReEdMaN, MDD. 